University of Nebraska - Lincoln

DigitalCommons@University of Nebraska - Lincoln

Nebraska Cooperative Fish \& Wildlife Research Nebraska Cooperative Fish \& Wildlife Research Unit -- Staff Publications

9-2019

\title{
Public Access for Pheasant Hunters: Understanding an Emerging Need
}

Lyndsie S. Wszola

Anastasia E. Madsen

Erica F. Stuber

Christopher J. Chizinski

Jeffrey J. Lusk

See next page for additional authors

Follow this and additional works at: https://digitalcommons.unl.edu/ncfwrustaff

Part of the Aquaculture and Fisheries Commons, Environmental Indicators and Impact Assessment Commons, Environmental Monitoring Commons, Natural Resource Economics Commons, Natural Resources and Conservation Commons, and the Water Resource Management Commons

This Article is brought to you for free and open access by the Nebraska Cooperative Fish \& Wildlife Research Unit at DigitalCommons@University of Nebraska - Lincoln. It has been accepted for inclusion in Nebraska Cooperative Fish \& Wildlife Research Unit -- Staff Publications by an authorized administrator of DigitalCommons@University of Nebraska - Lincoln. 


\section{Authors}

Lyndsie S. Wszola, Anastasia E. Madsen, Erica F. Stuber, Christopher J. Chizinski, Jeffrey J. Lusk, J. Scott Taylor, Kevin L. Pope, and Joseph J. Fontaine 


\title{
Public Access for Pheasant Hunters:
} Understanding an Emerging Need

LYNDSIE S. WSZOLA, ${ }^{\mathbf{1}}$ School of Biological Sciences, Nebraska Cooperative Fish and Wildlife Research Unit, University of Nebraska-Lincoln, 3310 Holdrege Street, Lincoln, NE 68583, USA

ANASTASIA E. MADSEN, Nebraska Cooperative Fish and Wildlife Research Unit, University of Nebraska-Lincoln, 3310 Holdrege Street, Lincoln, NE 68583, USA

ERICA F. STUBER, Nebraska Cooperative Fish and Wildlife Research Unit, University of Nebraska-Lincoln, 3310 Holdrege Street, Lincoln, NE 68583, USA

CHRISTOPHER J. CHIZINSKI, School of Natural Resources, University of Nebraska-Lincoln, 3310 Holdrege Street, Lincoln, NE 68583, USA

JEFFREY J. LUSK, Nebraska Game and Parks Commission, 2200 N 33rd St, Lincoln, NE 68503, USA

J. SCOTT TAYLOR, Pheasants Forever and Midwest Association of Fish and Wildife Agencies, Brookings, SD 57006, USA

KEVIN L. POPE, U.S. Geological Survey, Nebraska Cooperative Fish and Wildlife Research Unit, University of Nebraska-Lincoln, 3310 Holdrege Street, Lincoln, NE 68583, USA

JOSEPH J. FONTAINE, Nebraska Cooperative Fish and Wildlife Research Unit, University of Nebraska-Lincoln, 3310 Holdrege Street, Lincoln, NE 68583, USA

\begin{abstract}
Ring-necked pheasant (Phasianus colchicus; i.e., pheasant) hunting participation is declining across North America, reflecting a larger downward trend in American hunting participation and threatening benefits to grassland conservation and rural economies. To stabilize and expand the pheasant hunting population, we must first identify factors that influence pheasant hunter participation. We used an extensive in-person hunter survey to test the hypothesis that hunter demographics interact with social-ecological traits of hunting locations to affect hunter decisions, outcomes, and perceptions. We built a series of Bayesian mixed effects models to parse variation in demographics, perceptions, and hunt outcomes of pheasant hunters interviewed at public access hunting sites across 3 regions in Nebraska, USA, that varied in pheasant abundance and proximity to urban population centers. Among pheasant hunters in Nebraska, access to private lands was negatively related to the human population density of a pheasant hunter's home ZIP code and the distance a hunter had traveled to reach a hunting location. Pheasant hunters interviewed closer to metropolitan areas tended to be more urban and travel shorter distances, and their parties were more likely to include youth but less likely to include dogs. Hunter satisfaction was positively associated with seeing and harvesting pheasants and hunting with youth. Whereas youth participation and the number of pheasants seen varied by study region, hunter satisfaction did not differ across regions, suggesting that hunters may calibrate their expectations and build their parties based on where they plan to hunt. The variation in hunter demographics across hunting locations and disconnects between social and ecological correlates of hunter satisfaction suggests that diverse pheasant hunting constituencies will be best served by diverse pheasant hunting opportunities. (c) 2019 The Wildlife Society.
\end{abstract}

KEY WORDS Great Plains, hunter recruitment and retention, Nebraska, Phasianus colcbicus, pheasant hunting, ring-necked pheasant, social-ecological systems.

Ring-necked pheasant (Phasianus colcbicus; i.e., pheasant) hunting in North America has created conservation, social, and economic benefits for ecosystems, hunters, and communities (Erickson and Wiebe 1973); however, the future benefits of pheasant hunting are increasingly uncertain. Despite considerable investment in hunter recruitment, retention, and reactivation (R3) programs, pheasant hunting in North American continues to decline, reflecting broader declines in hunter participation (Karns et al. 2015, U.S. Fish

Received: 19 May 2018; Accepted: 10 September 2019

${ }^{1}$ E-mail: Lyndsiewszola5@gmail.com and Wildlife Service [USFWS] 2018). Approaches to fostering hunter participation have traditionally focused on ecological objectives including improving game populations (Hendee 1974), but game abundance alone cannot explain rates of hunter participation (Mehmood et al. 2003, Vrtiska et al. 2013). The R3 programs of wildlife agencies and nongovernmental organizations have begun to address the social dimensions of hunter participation by focusing on hunting access and the quality of the hunter experience while providing training to individuals and families (Stayton 2017). Although R3 efforts appear successful at promoting a positive perception of hunting, the efficacy of R3 efforts at ensuring large-scale, long-term hunter recruitment and retention is 
unproven (Responsive Management and the National Wild Turkey Federation 2011).

Limitations on the success of $\mathrm{R} 3$ programs may be due in part to an incomplete understanding of the social, psychological, and ecological processes that underlie hunter participation (Decker et al. 1984, Manfredo et al. 2003, Larson et al. 2014a). Hunter satisfaction (i.e., the degree to which a hunting experience fulfills or exceeds a hunter's expectations), for example, affects future hunting participation (Oliver 1980, Manfredo et al. 2004, Brunke and Hunt 2007), and is shaped by the expectations hunters bring to a hunt and their experience during their hunt. Changes in the ecological landscape, including game abundance, affect the hunting experience (Tomeček et al. 2015), but so do changes in social, economic, and demographic variables such as the distribution of the human population and the social ties that facilitate hunting access (Stedman et al. 2008, Larson et al. 2014a). To understand the underlying mechanisms influencing declining participation in pheasant hunting, researchers and managers must understand how the complex social and ecological conditions that affect the hunting experience interact to shape hunter satisfaction and thus R3 success.

Among the most profound changes in the landscape of hunting is the change in hunter demographics. The United States population, hunters included, is rapidly urbanizing (Environmental Protection Agency 2015, USFWS 2018). The needs and preferences of an urban hunter population are likely substantively different from those of past, largely rural hunter populations (Schulz et al. 2003). Modern urban hunters have fewer social connections to rural landowners and therefore are often more limited in their access to places to hunt (Lauber and Brown 2000, Heberlein and Ericsson 2005, Walberg et al. 2018). Illustrating the complexity of the social and ecological interactions that shape the hunting experience, a hunter's site choice, rate of game encounter, and satisfaction is influenced by the hunting lands accessible to a hunter; indeed, hunters limited to hunting locations open to the public may be more likely to drop out of hunting entirely if they lack people to hunt with, spend less time hunting, or harvest fewer animals (Enck et al. 2000, Stedman et al. 2008). Despite the potential costs and limitations of hunting exclusively on public lands, members of an increasingly urban hunting constituency may lack alternative access options, contributing to the rise of a new group of public lands hunters whose needs and identities are poorly understood.

To identify and engage a diverse pheasant hunting constituency, it is essential to identify factors influencing pheasant hunting access. More importantly, researchers and managers must establish how site choice influences the hunting experience, and how the hunting experience, in turn, influences future participation and site choice decisions to design hunter engagement strategies for diverse hunter groups. Motivations for hunting are diverse, ranging from cultural to practical (Ryan and Shaw 2011). Demographic variation among hunters (e.g., the presence of children in the group, population density of hunter origin) may affect a hunter's needs and expectations of an outdoor recreation experience (Harmon 2017). Hunters from urban and suburban areas and hunting parties with children may be more likely to seek opportunities close to home because they provide an experience at a lower time and financial cost (Andersen et al. 2010). More casual or lower-income hunters may also be less likely to invest in specialized hunting resources, such as hunting dogs, that are expensive and time-consuming to train and maintain but also potentially increase a hunter's ability to find and harvest pheasants. In contrast, more avid hunters, affluent hunters, and those without childcare responsibilities may be more likely to seek opportunities with high game abundance even if such opportunities require farther travel (Hussain et al. 2010).

Access to and choice of hunting opportunity is a complex social-ecological phenomenon that may depend upon factors such as how far a hunter has traveled to reach their hunting destination and whether they come from a rural location where hunting access relationships and traditions of asking for access are maintained, or from a less connected urban area (Stedman et al. 2008, Ribot and Peluso 2009, Walberg et al. 2018). Some hunters may even pay for private hunting access, creating a dynamic in which access can be dependent upon economic status (Mozumder et al. 2007, Johnson et al. 2012). Even when hunters have access to some private lands, the distribution of hunting opportunities in space correlates with other aspects of hunter motivation and participation. Hunters generally may prefer local opportunities, creating the potential for distance to affect how urban and rural hunters make site choice decisions (Schulz et al. 2003). Similarly, hunters with children may wish to access locations within a day trip radius of their homes, whereas older (i.e., past childrearing age, retired) or more affluent hunters may be willing to make longer trips (Offenbach and Goodman 1994). Hunters with dogs may be willing to travel farther for the opportunity to work their dogs or hunt areas with more abundant pheasant populations (Kaltenborn and Andersen 2009, Chitwood et al. 2011). Conversely, more casual hunters and hunters without dogs may not perceive traveling farther to be worthwhile.

Whereas seeing and harvesting game are ostensibly the purposes of hunting, it is important to understand the correlates of seeing and harvesting pheasants when discussing pheasant hunter demographics, hunting experience, and satisfaction. The number of pheasants seen and harvested may vary geographically as a function of the available pheasants but also as a function of hunting technique (e.g., the number of dogs in a party; Mecozzi and Guthery 2008). Hunters who travel farther or spend more time in urban areas may be less familiar with the landscape and therefore have a lower pheasant encounter rate (Hunt et al. 2007). Hunter age also has the potential to affect the number of game animals hunters see and harvest because older hunters may be more skilled and experienced but also more subject to the physical limitations of age (Boulanger et al. 2006, Ward et al. 2008).

Though managers may have the most direct impact on factors like hunter access and game populations, hunters' perceptions of their experience and future hunting intentions 


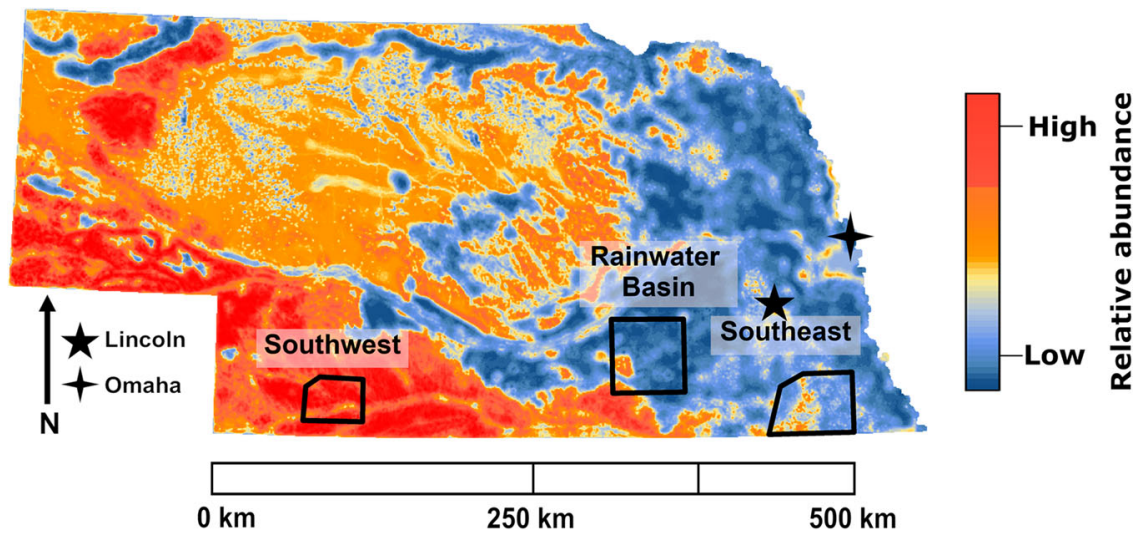

Figure 1. Three study regions where we interviewed ring-necked pheasant hunters on public access hunting lands in Nebraska, USA, 2014-2017. Wild pheasant relative abundance was greatest in the Southwest, intermediate in the Rainwater Basin, and lowest in the Southeast.

are the proximate drivers of future hunting participation. Hunters may derive satisfaction from multiple non-exclusive sources, including seeing and harvesting game, mentoring youth, and the expectations they set based on the location in which they choose to hunt (Hendee et al. 1974, Vaske et al. 1986, Frey et al. 2003, Brunke and Hunt 2007). We tested the hypothesis that hunter demographics interact with socialecological traits of hunting locations to affect hunter decisions, outcomes, and perceptions. We addressed this hypothesis by exploring correlates of access to private hunting lands, choice of hunting region, pheasants seen, pheasants harvested, and hunter satisfaction of pheasant hunters on public access hunting lands that varied from urban-proximate with low relative pheasant abundance to rural with high relative pheasant abundance across Nebraska, USA.

\section{STUDY AREA}

We conducted the study from 25 October 2014 to 31 January 2017 in Nebraska. Nebraska contains a range of conditions that reflect shifts in land use and human populations across the pheasant range, from rural to urban and from rangelands and small grains (e.g., wheat and sorghum) to row cropped corn and soybeans (U.S. Department of Agriculture 2012, Wright and Wimberly 2013). The eastern, wetter side of the state is dominated by row cropped corn and soybeans and contains Lincoln and Omaha, the state's major urban areas. In contrast, the more arid western side of the state is very rural and dominated by working rangeland and small grain crops. Like much of the pheasant range, Nebraska is predominately private land ( 97\%; Bishop et al. 2011), and although it is possible to hunt pheasants on many rural lands in Nebraska, hunting access to private lands across the United States is often limited to friends and family of the landowner (Sigmon 2004). Public access properties, including Wildlife Management Areas (WMA), State Recreation Areas (SRA), USFWS Waterfowl Production Areas (WPA), United States Army Corps of Engineers reservoirs, and private lands enrolled in public access programs, such as the Nebraska Open Fields and Waters Program (OFW; partially funded by the Voluntary Public Access and Habitat Incentive Program; Lucas 2013), provide important public hunting opportunities.

Our study area included 3 regions that totaled $7,952 \mathrm{~km}^{2}$ of land area, designated as Southwest, Rainwater Basin, and Southeast. We selected the regions in consultation with the Nebraska Game and Parks Commission (NGPC) to represent the state's important public hunting opportunities. Each region included a relatively high density of public access sites but differed in land use, pheasant abundance, and human population density (Fig. 1, Table 1; Bishop et al. 2011, NGPC 2017, Stuber et al. 2017). Wild pheasant abundance was consistently greatest in the Southwest, intermediate in the Rainwater Basin, and lowest in the Southeast (Fig. 1; Jorgensen et al. 2014, NGPC 2016a). Beyond their varying pheasant abundance, the 3 study regions embodied much of the social and ecological variation present in Nebraska.

\section{Southwest Region}

The 1,590-km² semi-arid Southwest Region included parts of Hitchcock, Hayes, and Red Willow counties and was composed of mixed-grass prairie, rangeland, small grain agriculture, and riparian cottonwood (Populus spp.)-juniper (Juniperus spp.) forest, with irrigated row crops in river valleys. It was characterized by a cold semi-arid climate that averaged $53 \mathrm{~cm}$ of precipitation/year with cold dry winters and hot dry summers punctuated by severe storms (National Oceanic and Atmospheric Association [NOAA] 2016). The region had an elevation of approximately $800 \mathrm{~m}$ above sea level and the topography included rolling hills and canyons covered primarily by loess mixed-grass and

Table 1. Region area $\left(\mathrm{km}^{2}\right)$, mean number of sites surveyed per year, mean percent of study region open to public hunting per region per year, and human population density of regions (people/ $\mathrm{km}^{2}$ ) during the 2014-2016 ring-necked pheasant hunting seasons in Nebraska, USA.

\begin{tabular}{lcccc}
\hline Region & $\begin{array}{c}\text { Region } \\
\text { area }\end{array}$ & $\begin{array}{c}\text { Number } \\
\text { of sites }\end{array}$ & $\begin{array}{c}\text { \% public } \\
\text { access land }\end{array}$ & $\begin{array}{c}\text { Population } \\
\text { density }\end{array}$ \\
\hline Southwest & 1,590 & 423 & 6.1 & 3 \\
Rainwater Basin & 3,440 & 365 & 1.8 & 6 \\
Southeast & 2,922 & 633 & 2.8 & 6 \\
\hline
\end{tabular}


sandsage mixed-grass prairie (Ratcliffe and Hammond 2002). In addition to pheasants, the Southwest hosted rich bird and mammal communities, with notable fauna including northern bobwhites (Colinus virginianus), sharptailed grouse (Tympanuchus phasianellus), greater prairie chickens (Tympanuchus cupido), wild turkeys (Meleagris gallopavo), diverse migratory waterfowl, bobcats (Lynx rufus), coyotes (Canis latrans), white-tailed deer (Odocoileus virginianus), and mule deer (Odocoileus hemionus).

\section{Rainwater Basin Region}

The Rainwater Basin Region, which included primarily Hamilton, York, Clay, and Filmore counties, was characterized by tallgrass prairie and wetlands in a row crop matrix. The Rainwater Basin region experienced a hotsummer humid continental climate, with warm, wet summers and cold, dry winters at an elevation of approximately $545 \mathrm{~m}$ above sea level with precipitation averaging $73 \mathrm{~cm} /$ year (NOAA 2016). The largely flat Rainwater Basin region was historically defined by upland and lowland tallgrass prairie interspersed with a high density of ephemeral playa wetlands, locally called rainwater basins. Although most of the region, including many of the wetlands, are now used for corn and soybean cultivation, the Rainwater Basin still served as an essential stopover on the Central Flyway for large numbers of migrating waterfowl and shorebirds (Bishop and Vrtiska 2008). The fauna of the Rainwater Basins additionally included many mammal species, especially white-tailed deer, coyotes, and raccoons (Procyon lotor).

\section{Southeast Region}

The Southeast Region included grasslands, wetlands, and riparian forest in a mainly row crop and residential matrix. The region was characterized by rolling hills at an elevation of $390 \mathrm{~m}$ above sea level and a hot-summer humid continental climate with warm, wet summers, and cold, dry winters, with average precipitation of $79 \mathrm{~cm} /$ year (NOAA 2016). The Southeast Region was historically dominated by upland tallgrass prairie, interspersed with fire-maintained oak savannah and saline wetlands. Predominate land uses in the region were agricultural and urban, with the result that the vegetation regime was dominated by corn and soybean agriculture, with remnant prairies and oak savannahs maintained by grazing and conservation (Parton et al. 2005). In addition to pheasants, notable fauna included northern bobwhites, greater prairie chickens, wild turkeys, white-tailed deer, coyotes, and raccoons. The Southeast is also the only region we surveyed where the NGPC R3 efforts included releasing pheasants, often for publicized youth hunts.

\section{METHODS}

\section{Data Collection}

We interviewed pheasant hunters on public access hunting lands across Nebraska to create a fine-scale portrait of contemporary hunter demographics, perceptions, and outcomes. We monitored public access sites for hunters each day starting the last Saturday in October (opening day of pheasant season) to 31 January (the last day of pheasant season) 2014-2015, 2015-2016, and 2016-2017 (average of 97 survey days/season; NGPC 2016b; Fig. 1). Each study season therefore refers to the fall hunting season through the following January (e.g., the 2014 study season refers to the period from the last Saturday in Oct 2014 to 31 Jan 2015). We defined a sampling location as a Public Land Survey System section of land (i.e., 259 ha; U.S. Geological Survey 2018) that included any land open to public hunting. All sampling locations were no larger than a single section, but multiple sampling locations could be adjacent to each other (NGPC 2016c). The study included all sites within each region that were accessible from the road.

We visited each site daily in a systematic bus route design that randomized start time (morning or afternoon), start location (3-5 start locations/route), and route direction (clockwise, counter-clockwise; Pollock et al. 1994). Morning routes started at the beginning of legal hunting hours (30 min before sunrise) and continued until noon. Afternoon routes began between 1230 and 1330, according to sunset times, and continued until 30 minutes after sunset, the end of pheasant hunting hours. We drew bus routes to maximize the number of sites within each study region that could be sampled within the daily sampling window given the available road network. Thus, we sampled all sites for hunters at least once daily, either in the morning or the afternoon. At the completion of the bus route survey, interviewers revisited properties where vehicles or individuals were present to identify when the party exited the property. For locations that remained occupied, interviewers monitored points of exit until the party exited and was interviewed, or the survey shift ended at either 1300 or 1 hour after sunset.

Following a standardized creel survey protocol (Pollock et al. 1994; Appendix A), we conducted complete-trip interviews of hunters exiting public access sites. Specifically, if we detected a party exiting a public access site at any point during the systematic bus route survey described below, interviewers approached the party and asked them a series of questions aimed at identifying target species, hunter access to private lands $(1=$ any private lands access in the study region, or $0=$ no private lands access in the study region), hunter age, home ZIP code, number of youth, number of dogs, number of pheasants seen, and harvest success. Hunting parties may have similar experiences yet be composed of demographically distinct individuals. We therefore recorded one value per hunter of age, gender, and home zip code, and one value per party of target species, private lands access, number of dogs, the number of pheasants seen, and the number of pheasants harvested. In the 2014-2015 and 2015-2016 field seasons, we also measured hunter satisfaction by asking parties to what extent their hunting experience met expectations (on a scale from 1 [i.e., failed to meet expectations] to 3 [i.e., met expectations] to 5 [i.e., exceeded expectations]; Brunke and Hunt 2007). We interviewed only parties that included $\geq 1$ individual age 19 or older, per institutional human subjects policy, and 
conducted all work under Institutional Review Board approvals from the University of Nebraska Lincoln (20120912892EX and 20160616155EP).

\section{Analysis}

We filtered the interview dataset to only those hunters who were primarily pursuing pheasants, and calculated party sizes from the reported numbers of adult men, adult women, and youths in each party. We used reported home ZIP codes to assign hunters Nebraska residency status (inside or outside $\mathrm{NE}$ ) and estimated home population density (residents $/ \mathrm{km}^{2}$ of land area) and median household income values from the 2016 American Community Survey, which collects a more limited set of up-to-date demographic information between decennial censuses (American Community Survey 2016 5-year estimates; U.S. Census Bureau 2018a). We additionally assigned each interviewed hunter a distance from home measure by computing the driving distance from each hunter's home ZIP code to the location where we interviewed them using the Google Maps (Google, Mountain View, CA, USA) driving distance application programming interface and the $\mathrm{R}$ package gmapsdistance (Melo et al. 2018).

We evaluated our research questions using a series of generalized linear mixed models (GLMMs) estimated in a Bayesian framework (Bolker et al. 2009). We fit all GLMMs in package MCMCglmm (Hadfield 2010, 2018) in the $\mathrm{R}$ statistical programming environment ( $\mathrm{R}$ Core Development Team 2018) using default priors. Bayesian models treat all variables as random (Hobbs and Hooten 2015). When we refer to fixed and random effects in the following paragraphs, we are therefore differentiating between model terms for which we estimate and report parameter values and those for which we do not. Random effects for which we do estimate parameters in a given model may be interpreted as nuisance variables that are marginalized in the context of the model. We estimated parameter means and 95\% credible intervals using 10,000 draws from the joint posterior distribution. We confirmed model convergence using trace plots and Gelman-Rubin diagnostics (Gelman and Rubin 1992, Brooks and Gelman 1998, Plummer et al. 2016; code and anonymized data available online in Supporting Information).

We first assessed sources of variation in private land hunting access among public access pheasant hunters by fitting a binomial GLMM with a logit link that related a hunter's private lands access status $(1=$ any private lands access in the study region or $0=$ no private lands access in the study region) to the fixed effects of hunter age, home population density, median household income, and distance from home to interview location, with random effects of region and study year. For our second research question, we investigated demographic variation by region. In Nebraska, the majority of the human population is located in Lincoln and Omaha on the eastern side of the state, whereas the most abundant pheasant populations are in the Southwest study region. The discontinuity of human and pheasant populations creates a dynamic wherein the majority of the pheasant hunting public would have to travel farther to hunt abundant pheasant populations, or hunt less abundant pheasant populations and the limited number of stocked locations closer to home. We therefore investigated demographic variation among hunters interviewed in different regions by fitting a series of GLMMs that evaluated how a hunter's choice of region was related to hunter origin population density via a Gaussian model with an identity link, distance between home ZIP code and interview location via a Gaussian model with an identity link, the likelihood that youth were included in the party via a binomial model with a logit link, and the likelihood that dogs were included in the party via a binomial model with a logit link. Each region choice model included a random effect of study year and was estimated with intercepts suppressed.

For our next 2 questions, we assessed sources of variation in the number of pheasants seen per party and the number of pheasants harvested per party by fitting 2 GLMMs including as fixed effects region, hunter home population density, distance traveled, number of dogs in the party, and age, with year as a random effect. We used the Poisson model family with a log link for both models and suppressed the intercepts, as above. Finally, we assessed sources of variation in pheasant hunter satisfaction by fitting an ordinal GLMM with a probit link predicting the degree to which a hunt met the hunter's expectations (on a scale of 1 [i.e., failed to meet expectations] to 5 [i.e., exceeded expectations]), with fixed effects of study region, pheasants seen, pheasants harvested, and number of youth in the party, with a random effect of study year. Although parties share some experiences, we treated individual hunters as independent samples within the models to parse the effects of differences in hunter demographics. We assigned each hunter the target species, number of dogs, number of pheasants seen, number of pheasants harvested, and satisfaction variables reported at the party scale, with their individual home ZIP code, travel distance, age, gender, and income estimates.

\section{RESULTS}

We interviewed 727 parties that included 1,293 pheasant hunters. The mode party size was 2 hunters ( $31 \%$ of all parties) and $87 \%$ of parties contained 1-4 hunters (Tables 2-4). Hunters were an average of $47 \pm 0.41$ (SE) years old and the oldest hunter interviewed was 104 . Forty-two percent of parties interviewed had hunting access to private lands and $58 \%$ of hunters were Nebraska residents. Hunters had a censusestimated median household income of $\$ 61,604 \pm \$ 568$ and originated from ZIP codes with mean population density of $492 \pm 19$ people $/ \mathrm{km}^{2}$. The Southeast Region had the highest rate of youth participation ( $28 \%$ of parties included $\geq 1$ youth hunter), but when we removed pheasant release sites $(n=4)$, which often coincided with youth hunts, from the analysis, the Southeast did not have higher youth participation than the other regions (only $5 \%$ of non-release site parties contained $\geq 1$ youth). Among the $17 \%$ of parties that contained $\geq 1$ youth hunter, the mode number of youth/party was 1 (56\%). Of the 
Table 2. Descriptive characteristics of ring-necked pheasant hunting parties on public access hunting lands in Nebraska, USA, during the $2014-2016$ pheasant hunting seasons. All modes refer to the subset of values $>0$ and are shown with the percent of values that equaled the mode.

\begin{tabular}{|c|c|c|c|c|c|c|c|c|c|}
\hline Region & $\begin{array}{c}\text { Number of } \\
\text { parties }\end{array}$ & $\begin{array}{c}\text { Mode } \\
\text { party size }\end{array}$ & $\begin{array}{c}\% \text { mode } \\
\text { party size }\end{array}$ & $\begin{array}{l}\% \text { with } \\
\text { youth }\end{array}$ & $\begin{array}{c}\text { Mode number } \\
\text { of youth }\end{array}$ & $\begin{array}{c}\% \text { mode } \\
\text { number of } \\
\text { youth }\end{array}$ & $\begin{array}{c}\begin{array}{c}\% \\
\text { with } \\
\text { dogs }\end{array} \\
\end{array}$ & $\begin{array}{c}\text { Mode } \\
\text { number } \\
\text { of dogs }\end{array}$ & $\begin{array}{c}\% \text { mode } \\
\text { number } \\
\text { of dogs }\end{array}$ \\
\hline Rainwater Basin & 199 & 1 & 38 & 10 & 1 & 65 & 93 & 1 & 46 \\
\hline Southwest & 329 & 2 & 30 & 15 & 1 & 67 & 89 & 1 & 48 \\
\hline All & 727 & 2 & 31 & 17 & 1 & 56 & 87 & 1 & 50 \\
\hline
\end{tabular}

Table 3. Private lands access, harvest success, and expectation fulfillment rating $(1=$ failed to meet expectations, $3=$ met expectations, $5=$ exceeded expectations) of ring-necked pheasant hunters in Nebraska, USA, during the 2014-2016 pheasant hunting seasons. All modes refer to the subset of values $>0$ and are shown with the percent of values that equaled the mode. Mean and standard error of harvest refers to the number of pheasants harvested by parties who harvested $\geq 1$ pheasant.

\begin{tabular}{|c|c|c|c|c|c|c|c|c|}
\hline \multirow[b]{2}{*}{ Region } & \multirow[b]{2}{*}{$\%$ private access } & \multicolumn{2}{|c|}{ Pheasants seen } & \multirow[b]{2}{*}{$\%$ success } & \multicolumn{2}{|c|}{ Harvest } & \multirow[b]{2}{*}{ Mode expectations rating } & \multirow[b]{2}{*}{$\%$ mode expectations rating } \\
\hline & & $\bar{x}$ & $\mathrm{SE}$ & & $\bar{x}$ & SE & & \\
\hline Rainwater Basin & 36 & 6.04 & 0.51 & 35 & 1.96 & 0.11 & 3 & 43 \\
\hline All & 42 & 6.43 & 0.40 & 34 & 2.15 & 0.06 & 3 & 39 \\
\hline
\end{tabular}

$87 \%$ parties that hunted with $\geq 1 \mathrm{dog}$, the mode number of dogs was $1(50 \%)$ and $93 \%$ of parties contained $0-2$ dogs. Hunters traveled a mean distance of $407.91 \pm 13.86 \mathrm{~km}$ from their home ZIP code and the longest observed travel distance was $5,360 \mathrm{~km}$, from Alaska to the Southwest Region. Seventythree percent of parties saw $\geq 1$ pheasant, and the mean number of pheasants seen per hunt by parties who saw any was $9 \pm 1$. Among the $34 \%$ of parties that harvested $\geq 1$ pheasant, the mean number of pheasants harvested was $2 \pm 0$. The maximum number of pheasants harvested by any one party was 10. Expectation fulfillment ratings ranged from 1-5 with a mode reported expectation fulfillment of 3 , met expectations (39\%), and $80 \%$ of hunters said their hunt met or exceeded their expectations.

The likelihood that a pheasant hunter interviewed on public access hunting lands had hunting access to private lands was negatively related to their home population density and travel distance but was not related to age or their ZIP code's median household income (Table 5; Fig. 2). Pheasant hunters differed by survey region in their home population density, distance traveled, and the presence of youth and dogs in hunting parties (Tables 2-5). Hunters in the Southeast Region originated from ZIP codes with higher mean population densities than hunters in the Rainwater Basin and Southwest Regions and traveled shorter distances than hunters in the other 2 regions (Table 4). Parties in the Southeast were more likely to include youth hunters but less likely to include dogs (Table 2).

Hunters in the Southwest saw the greatest numbers of pheasants, but their harvest did not differ appreciably from that of other hunters in other regions (Tables 3-5). Whereas the credible intervals of the region harvest parameter estimates did not overlap zero, hunter success and the number of pheasants harvested by successful hunters was biologically quite similar across regions (Tables 3-5). Additionally, the number of pheasants seen and the number of pheasants harvested increased with the number of dogs in the party but did not vary by distance traveled (Table 5). For example, a party in the Southwest Region with no dogs would be predicted to see 2.00 pheasants and harvest 0.28 pheasants, whereas a party with 1 dog would be predicted to see 2.25 pheasants and harvest 0.39 pheasants.

Hunter expectation fulfillment was positively related to the number of pheasants seen, the number of pheasants harvested, and the number of youth in the party but was not related to region (Table 5). For example, the mode expectation fulfillment rating of hunters in parties with youth was 5 , exceeded expectations (42\%), whereas the mode expectation fulfillment rating of hunters in parties without youth was 3, met expectations (43\%). Likewise, the mode

Table 4. Sample sizes and demographics of individual ring-necked pheasant hunters interviewed on public access hunting lands in Nebraska, USA, during the 2014-2016 pheasant hunting seasons, including number of hunters interviewed, percent of hunters that were Nebraska residents, mean hunter age, mean travel distance $(\mathrm{km})$, mean home population density (people $/ \mathrm{km}^{2}$ ), and mean income of their home ZIP code per the American Community Survey (\$/yr).

\begin{tabular}{|c|c|c|c|c|c|c|c|c|c|c|}
\hline \multirow[b]{2}{*}{ Region } & \multirow[b]{2}{*}{ Number of hunters } & \multirow[b]{2}{*}{$\%$ NE residents } & \multicolumn{2}{|c|}{ Age } & \multicolumn{2}{|c|}{ Distance traveled } & \multicolumn{2}{|c|}{ Population density } & \multicolumn{2}{|c|}{ Income (\$) } \\
\hline & & & $\bar{x}$ & $\mathrm{SE}$ & $\bar{x}$ & SE & $\bar{x}$ & SE & $\bar{x}$ & SE \\
\hline Rainwater Basin & 344 & 83 & 46 & 1 & 269.18 & 21.86 & 447 & 33 & 57,843 & 968 \\
\hline Southeast & 306 & 87 & 45 & 1 & 214.29 & 21.86 & 548 & 34 & 64,511 & 1,168 \\
\hline Southwest & 643 & 32 & 48 & 1 & 576.11 & 21.54 & 489 & 29 & 62,237 & 843 \\
\hline All & 1,293 & 58 & 47 & 0 & 407.91 & 13.86 & 492 & 19 & 61,604 & 568 \\
\hline
\end{tabular}


Table 5. Response variables, model families, predictor variables, posterior means ( $\beta$ ), and credible intervals for models assessing correlates of variation in demographics, perceptions, and outcomes of ring-necked pheasant hunters on public access hunting lands in Nebraska, USA, during the 2014-2016 pheasant hunting seasons. Asterisks indicate parameters with credible intervals not overlapping zero.

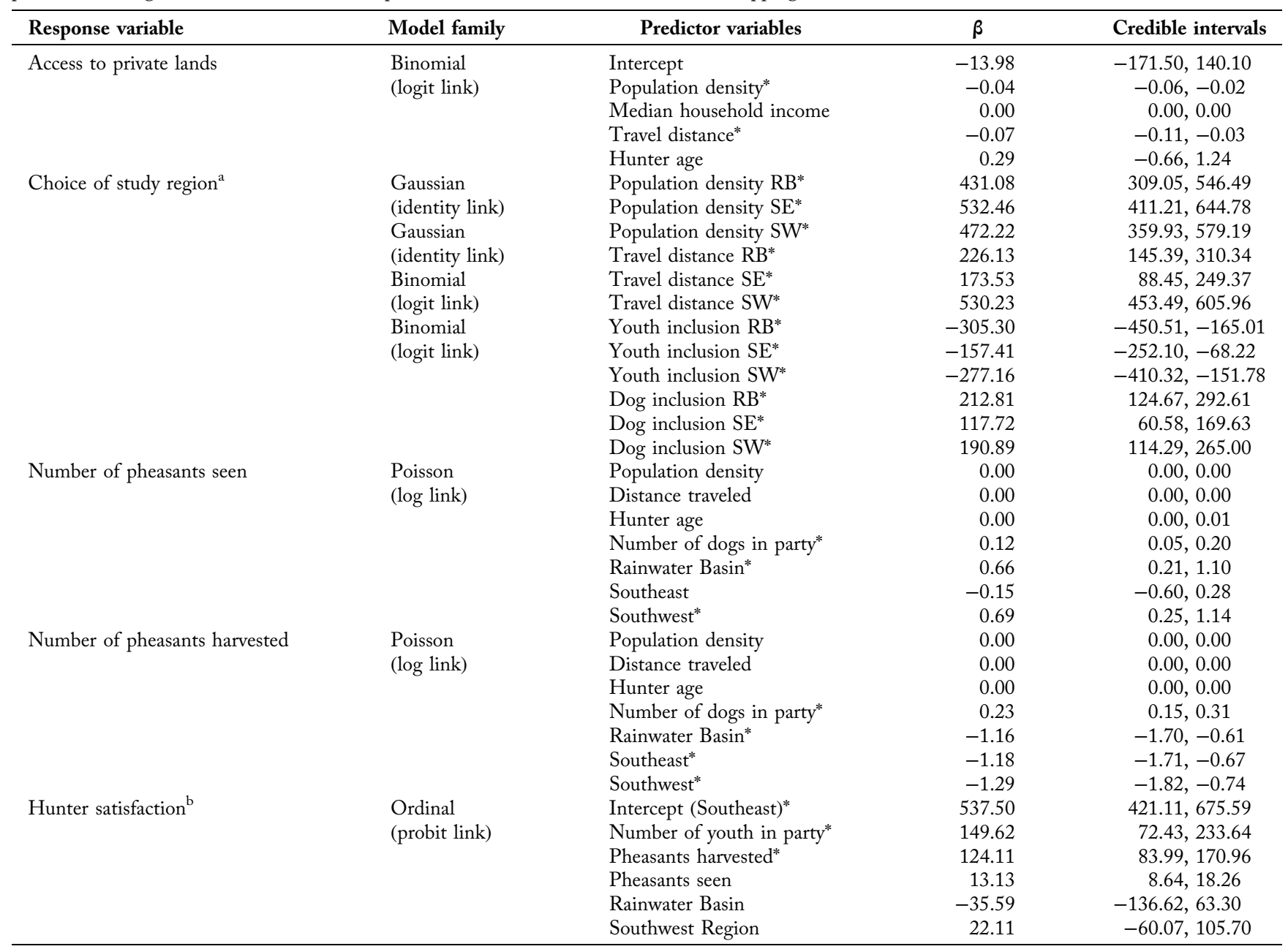

a Study regions: Rainwater Basin (RB), Southeast (SE), and Southwest (SW).

${ }^{\mathrm{b}}$ Response levels: 1 (failed to meet expectations) to 5 (exceeded expectations).
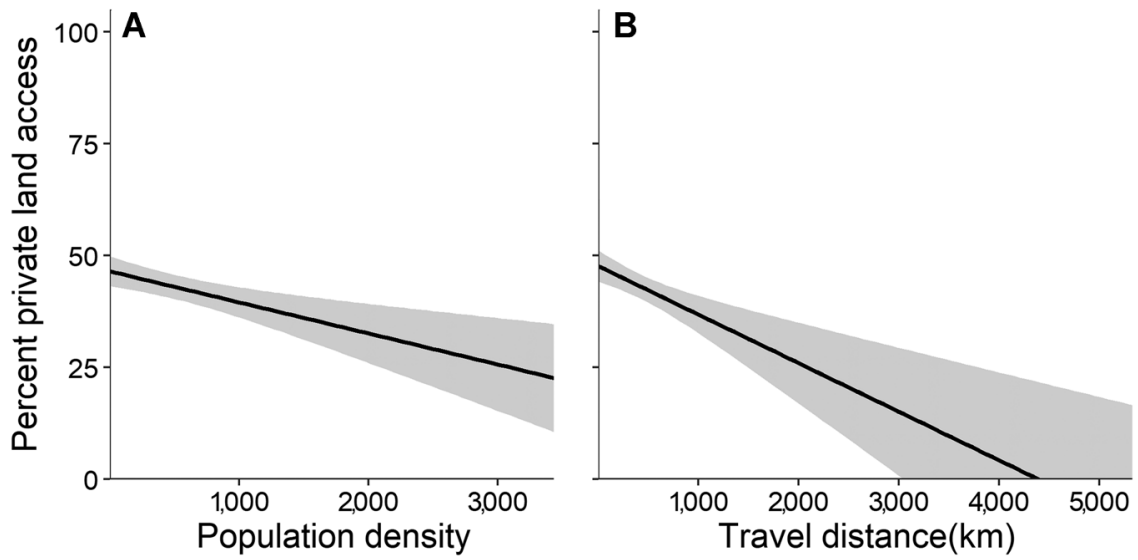

Figure 2. Effects of home population density and travel distance on a pheasant hunter's likelihood of having private lands hunting access in the region where they were interviewed in Nebraska, USA, 2014-2017. Likelihood of private lands access declined with increasing population density and travel distance. 
expectation fulfillment reported by hunters in parties that harvested $>0$ pheasants was $5(36 \%)$, whereas the mode expectation fulfillment reported by hunters in parties that harvested 0 pheasants was 3 (46\%).

\section{DISCUSSION}

Pheasant hunters are declining in abundance, threatening the future of the funding and advocacy pheasant hunting has provided for conservation, particularly of grasslands, through license sales and sportsman's groups (Johnson and Schwartz 1993, McCoy et al. 1999, Midwest Pheasant Study Group 2013, Taylor et al. 2018). The mechanisms influencing pheasant population declines have been studied and discussed extensively, resulting in increasingly targeted pheasant management strategies (Warner et al. 1984, Jorgensen et al. 2014, Pabian et al. 2015, NGPC 2016c). For pheasant management to create desirable conservation and economic outcomes, however, management must also facilitate hunter participation. Understanding what social and ecological factors influence pheasant hunter participation can help facilitate targeted hunter engagement strategies.

We found that expectation fulfillment, a proxy for hunter satisfaction, was positively related to the number of pheasants hunters harvested on public access hunting lands and the number of youth they included in their parties. Our results concur with previous evidence that seeing and harvesting game animals and spending time with family and friendsimprove the hunting experience (Bissell et al. 1998, Miller and Gaefe 2001, Frey et al. 2003, Schroeder et al. 2006). Whereas the number of dogs, the number of youth, travel distance, and the number of pheasants seen differed among regions, hunter expectation fulfillment did not, suggesting that hunters may calibrate their expectations and build their parties based on where they plan to hunt.

In the Southeast Region, for example, pheasant relative abundance is consistently the lowest of any region we surveyed (Fig. 1; Jorgensen et al. 2014, Stuber et al. 2017), but the region is located nearest to the Lincoln and Omaha metropolitan areas. Nebraska's 2 major metropolitan areas comprise $65 \%$ of the state's population, making publicaccess sites in the Southeast Region accessible as a day trip to the majority of Nebraska's population (U.S. Census Bureau 2018b). It is therefore not surprising that hunters interviewed in the Southeast Region originated from places with higher population densities, traveled shorter distances, and saw fewer pheasants than hunters in the other regions. Despite seeing fewer pheasants than did hunters in the Southwest and Rainwater Basin Regions, hunters in the Southeast Region had similar expectation fulfillment to hunters in the other regions, suggesting that there is more to understanding the hunting experience than just encountering game (Hendee 1974). Hunting parties in the Southeast Region were the most likely to include youth hunters, another correlate of hunter satisfaction in our findings and in other studies (Guttery et al. 2015, Everett and Nelson 2016). The similarities in stated expectation fulfillment despite differences in hunt outcomes among the various regions we surveyed appear to confirm our hypothesis that hunter demographics interact with social-ecological traits of hunting locations to affect hunter decisions, outcomes, and perceptions.

One such interaction may explain why parties that included youth did not prefer to hunt in places with the greatest likelihood of encountering pheasants. Traveling long distances to hunt is time-consuming and expensive, and may be especially daunting for hunters who wish to hunt with their children, as families with children face everincreasing demands on their time (Adams et al. 1989, Snellman et al. 2015). Similarly, there may be fewer benefits to investing in a long trip for causal pheasant hunters, such as those that may be unwilling or unable to invest time, money, and skill into dogs or other equipment (Johnson et al. 2012) that improve encounter rates with pheasants. As indicated by our findings, public access hunting opportunities located within 1-2 hours of major metropolitan areas can provide an upland hunting experience that is particularly appealing to casual hunters, especially those with children. Providing public access hunting opportunities with limited travel costs for casual hunters may even prove effective in locations with low pheasant abundance, as we saw in southeast Nebraska (Fig. 1). Still, improving pheasant harvest opportunities near metropolitan areas may add to overall hunter satisfaction and potentially increase hunter participation among urban hunters, even if such an objective requires strategic youth and family engagement events as suggested by Schulz et al. (2003). Indeed, the Southeast Region provided one of the state's only opportunities to hunt pheasants released on public land, which appears to have contributed to higher youth participation in the Southeast by increasing the likelihood that youth hunters will encounter pheasants. Although such put-andtake hunting events may spur short-term participation increases, they may also incur longer-term costs to the ecology of hunted populations and the culture of hunting wild birds, emphasizing the need for sustainable urban-serving hunting engagement strategies (Gamborg et al. 2016, Arroyo et al. 2017). We acknowledge that a metropolitan-oriented engagement strategy may be most effective in jurisdictions like Nebraska, where pheasant hunting skills and culture are retained by urban residents who grew up in rural landscapes or know others who did. Because migration from rural to urban areas characterizes urban and suburban populations across much of the pheasant range (White 2008), it may be worthwhile to evaluate whether recent urban residents in other locations may be reactivated into the sport by the availability of publicly accessible upland hunting opportunities, especially if such opportunities are marketed as a family activity.

In contrast to the Southeast Region's low pheasant abundance and proximity to urban areas, the largely rural Southwest Region had much higher pheasant abundance and was approximately equidistant from the LincolnOmaha metropolitan areas $(\sim 377 \mathrm{~km})$ and the Denver, Colorado, USA, metropolitan area $(\sim 422 \mathrm{~km})$. Southwest public access pheasant hunters traveled farther $(576 \mathrm{~km}$ on 
average compared to $269 \mathrm{~km}$ in the Rainwater Basin and $214 \mathrm{~km}$ in the Southeast) and were less likely to be Nebraska residents (only 32\%, compared to $83 \%$ in the Rainwater Basin and $87 \%$ in the Southeast) than hunters in the other survey regions. Coupled with the fact that hunting parties in the Southwest were more likely to hunt with dogs than hunters in the urban-proximate Southeast, it is reasonable to conclude that public access pheasant hunters in the Southwest were more avid pheasant hunters than those hunting close to the state's major metropolitan areas. Avid bird hunters invest more time and money in dog training and travel than do casual hunters to access high-quality pheasant hunting opportunities (Berrens and Adams 2008, Chitwood et al. 2011). The Southwest Region regularly sustains the greatest abundance of pheasants (Fig. 1), suggesting that the Southwest is an important regional destination for avid pheasant hunters who are willing to expend the time and money to travel from areas with high human population density, often from other states, in search of abundant pheasant populations on public access properties. The Southwest Region may thus represent another important component of a successful upland hunting access strategy. Avid hunters are more likely to consistently participate in hunting and are more likely to mentor new hunters (Enck and Brown 2008, James and Palmer 2012). Creating public access hunting opportunities with high pheasant abundance, even if not close to a population center, may be an effective means of engaging and retaining the most avid upland hunters who will be a consistent source of conservation funding and hunter mentorship.

The likelihood that pheasant hunters on public access hunting lands had access to private lands was negatively related to their home population density and the distance they traveled. Hunters, like the American population at large, are becoming increasingly urban; as of 2016, only $22 \%$ of hunters lived outside of a metropolitan statistical area (USFWS 2018). Younger, more urban people consequently represent one of the greatest opportunities for growth in hunting participation, and access to hunting land can be an important determinant of hunting participation (Miller and Vaske 2003, Stayton 2017). Our results suggest that public access upland hunting opportunities serve an increasingly important role in R3 efforts by providing an urban population a partial replacement for the social ties that have traditionally facilitated private land hunting access (White and Guest 2003, Larson et al. 2014b). We further propose that hunter satisfaction, a predictor of future participation, may be maximized by implementing access strategies that incorporate the diversity of interests represented by an increasingly diverse population of prospective hunters. Opportunities that provide access to abundant pheasant populations will likely attract more avid hunters, even if they require additional investment in time and travel, and public access hunting opportunities near population centers may prove attractive to casual hunters and families, even when pheasant densities are low. A successful pheasant hunter engagement strategy will leverage underlying social and ecological variation in hunting systems to provide diverse opportunities for increasingly diverse pheasant hunting populations.

\section{MANAGEMENT IMPLICATIONS}

We suggest that the future of pheasant hunting and the social, economic, and ecological benefits hunters provide, will benefit from an adaptive approach that embraces a diverse R3 strategy. Providing diverse upland hunting opportunities inclusive of dynamic hunter demographics may allow agencies and non-governmental organizations to engage an increasingly diverse hunting constituency. Future research efforts must prioritize adaptive development and implementation of hunter research, especially research investigating emerging differences between public access and traditional private lands hunters. To be successful, future R3 strategies must become just as targeted as the wildlife management efforts they support.

\section{ACKNOWLEDGMENTS}

Any use of trade, firm, or product names is for descriptive purposes only and does not imply endorsement by the United States Government. We thank the pheasant hunters and hunter survey technicians who generated the hunter survey data, L. M. Messinger for administering the Nebraska Hunter Survey, and P. W. Brubaker and L. W. Brubaker for insights on pheasant ecology and distribution. Funding for this project was received from Federal Aid in Wildlife Restoration project $\mathrm{W}-115-\mathrm{R}$, administered by the Nebraska Game and Parks Commission. C. J. Chizinski was supported by Hatch funds through the Agricultural Research Division at the University of Nebraska-Lincoln and from Federal Aid in Wildlife Restoration projects W-120-T-1, administered by the Nebraska Game and Parks Commission.

\section{LITERATURE CITED}

Adams, R., O. Bergland, W. Musser, S. Johnson, and L. Musser. 1989. User fees and equity issues in public hunting expenditures: the case of ring-necked pheasant in Oregon. Land Economics 65:376-385.

Andersen, O., J. Vittersø, B. Kaltenborn, and T. Bjerke. 2010. Hunting desertion in Norway: barriers and attitudes toward retention measures. Human Dimensions of Wildlife 15:450-466.

Arroyo, B., J. Caro, E. J. Muñoz-Adalia, S. Díaz-Fernández, M. DelibesMateos, M. Díaz-Fernández, and J. Viñuela. 2017. Reconciling economic and ecological sustainability: can non-intensive hunting of redlegged partridges be economically profitable? European Journal of Wildlife Research 63(14):2-10.

Berrens, R. P., and R. M. Adams. 2008. Applying contingent valuation in the design of fee hunting programs: pheasant hunting in Oregon revisited. Human Dimensions of Wildlife 3:11-25.

Bishop, A., A. Barenberg, N. Volpe, J. Riens, and R. Grosse. 2011. Nebraska Land Cover Dataset. Rainwater Basin Joint Venture, Grand Island, Nebraska, USA.

Bishop, A. A., and M. Vrtiska. 2008. Effects of the Wetlands Reserve Program on waterfowl carrying capacity in the Rainwater Basin Region of south-central Nebraska. A Conservation Effects Assessment Project Wildlife Component assessment. Rainwater Basin Joint Venture, Grand Island, Nebraska, USA. <https://www.nrcs.usda.gov/Internet/FSE_ DOCUMENTS/16/nrcs143_022300.pdf >. Accessed 15 Oct 2019.

Bissell, S. J., M. D. Duda, and K. C. Young. 1998. Recent studies on hunting and fishing participation in the United States. Human Dimensions of Wildlife 3:75-80.

Bolker, B. M., M. E. Brooks, C. J. Clarke, S. W. Geange, J. R. Poulsen, H. M. M. Stevens, and J. S. White. 2009. Generalized linear mixed models: a practical guide for ecology and evolution. Trends in Ecology and Evolution 24:127-135. 
Boulanger, J. R., D. E. Hubbard, J. A. Jenks, and L. M. Gigliotti. 2006. A typology of South Dakota muzzleloader deer hunters. Wildlife Society Bulletin 34:691-697.

Brooks, S. P., and A. Gelman. 1998. General methods for monitoring convergence of iterative simulations. Journal of Computational and Graphical Statistics 7:434-455.

Brunke, D., and K. Hunt. 2007. Comparison of two approaches for the measurement of waterfowl hunter satisfaction. Human Dimensions of Wildlife 12:443-457.

Chitwood, M. C., M. N. Peterson, and C. S. Deperno. 2011. Assessing dog hunter identity in Coastal North Carolina. Human Dimensions of Wildlife 16:128-141.

Decker, D. J., R. W. Provencher, and T. L. Brown. 1984. Antecedents to hunting participation: an exploratory study of the social-psychological determinants of initiation, continuation, and desertion in hunting. Outdoor Recreation Research Unit, Department of Natural Resources, Cornell University, Ithaca, New York, USA.

Enck, J. W., and T. L. Brown. 2008. 2007 statewide deer hunter survey: participation during the '06 seasons, opinions about hot button issues, and trends in characteristics of hunters (HDRU Publication 08-5). Cornell University, Department of Natural Resources, Human Dimensions Research Unit, Ithaca, New York, USA.

Enck, J. W., D. J. Decker, and T. L. Brown. 2000. Status of hunter recruitment and retention in the United States. Wildlife Society Bulletin 28:817-824.

Environmental Protection Agency. 2015. EPA's report on the environment: urbanization and population change. Office of Research and Development, U.S. Environmental Protection Agency, Washington, D.C., USA.

Erickson, R. E., and J. E. Wiebe. 1973. Pheasants, economics and land retirement programs in South Dakota. Wildlife Society Bulletin 1:22-27.

Everett, M. W., and C. M. Nelson. 2016. 'Flow' and satisfaction of Michigan youth waterfowl hunters: implications for hunter retention. Society and Leisure 39:290-302.

Frey, S., M. Conover, J. Borgo, and T. Messmer. 2003. Factors influencing pheasant hunter harvest and satisfaction. Human Dimensions of Wildlife $8: 277-286$.

Gamborg, C., F. S. Jensen, and P. Sandøe. 2016. A dividing issue: attitudes to the shooting of rear and release birds among landowners, hunters and the general public in Denmark. Land Use Policy 57:296-304.

Gelman, A., and D. B. Rubin. 1992. Inference from iterative simulation using multiple sequences. Statistical Science 7:457-511.

Guttery, M. R., T. A. Messmer, W. M. Brunson, J. D. Robinson, and D. K. Dahlgren. 2015. Declining populations of greater sage-grouse: hunter motivations when numbers are low. Animal Conservation 19:26-34.

Hadfield, J. 2010. MCMC methods for multi-response generalized linear mixed models: the MCMCglmm R package. Journal of Statistical Software 33:1-25.

Hadfield, J. 2018. MCMCglmm: MCMC generalized linear mixed models. https://cran.r-project.org/web/packages/MCMCglmm/index. html. Accessed 08 Oct 2019.

Harmon, B. S. 2017. Recreational angler site choice and behavior within midwestern reservoirs. Thesis, University of Nebraska-Lincoln, Lincoln, USA.

Heberlein, T., and G. Ericsson. 2005. Ties to the countryside: accounting for urbanites attitudes toward hunting, wolves, and wildlife. Human Dimensions of Wildlife 10:213-227.

Hendee, J. 1974. A multiple-satisfaction approach to game management. Wildlife Society Bulletin 2:104-113.

Hobbs, N. T., and M. B. Hooten. 2015. Bayesian models: a statistical primer for ecologists. Princeton University Press, Princeton, New Jersey, USA.

Hunt, L. M., B. N. Boots, and P. C. Boxall. 2007. Predicting fishing participation and site choice while accounting for spatial substitution, trip timing, and trip context. North American Journal of Fisheries Management 27:832-847.

Hussain, A., I. A. Munn, D. Hudson, and B. West. 2010. Attribute-based analysis of hunters' lease preferences. Journal of Environmental Management 91:2565-2571.

James, W., and D. Palmer. 2012. Hunting matters! "Hats On" mentoring campaign. North Carolina Wildlife Resources Commission, Raleigh, USA.
Johnson, D. H., and M. D. Schwartz. 1993. The Conservation Reserve Program and grassland birds. Conservation Biology 7:934-937.

Johnson, J. L., D. Rollins, and K. S. Reyna. 2012. What's a quail worth? A longitudinal assessment of quail hunter demographics, attitudes, and spending habits in Texas. Quail Symposium Proceedings 7:1-6.

Jorgensen, C. F., L. A. Powell, J. J. Lusk, A. A. Bishop, and J. J. Fontaine. 2014. Assessing landscape constraints on species abundance: does the neighborhood limit species response to local habitat conservation programs? PLoS ONE 9:e99339.

Kaltenborn, B., and O. Andersen. 2009. Habitat preferences of ptarmigan hunters in Norway. European Journal of Wildlife Research 55:407-413.

Karns, G. R., J. T. Bruskotter, and R. J. Gates. 2015. Explaining hunting participation in Ohio: a story of changing land use and new technology. Human Dimensions of Wildlife 20:484-500.

Larson, L. R., R. C. Stedman, D. J. Decker, M. R. Quartuch, W. F. Siemer, and M. S. Baumer. 2014a. Understanding non-traditional hunters in New York: initial insights and implications for recruitment and retention research. Human Dimensions Research Unit, Department of Natural Resources, Cornell University, Ithaca, New York, USA.

Larson, L. R., R. C. Stedman, D. J. Decker, W. F. Siemer, and M. S. Baumer. 2014b. Exploring the social habitat for hunting: toward a comprehensive framework for understanding hunter recruitment and retention. Human Dimensions of Wildlife 19:105-122.

Lauber, T. B., and T. L. Brown. 2000. Hunting access on private lands in Dutchess County. Human Dimensions Research Unit 00-12. Department of Natural Resources, New York State College of Agriculture and Life Sciences, Cornell University, Ithaca, New York, USA.

Lucas, F. 2013. H.R.2642: Federal agriculture reform and risk management act of 2013. https://www.congress.gov/bill/113th-congress/housebill/2642. Accessed 08 Oct 2019.

Manfredo, M. J., P. J. Fix, T. L. Teel, J. Smeltzer, and R. Kahn. 2004. Assessing demand for big-game hunting opportunities: applying the multiple-satisfaction concept. Wildlife Society Bulletin 32:1147-1155.

Manfredo, M. J., T. L. Teel, and A. D. Bright. 2003. Why are public values toward wildlife changing? Human Dimensions of Wildlife 8:287-306.

McCoy, T., M. Ryan, E. Kurzejeski, and L. Burger. 1999. Conservation Reserve Program: source or sink habitat for grassland birds in Missouri? Journal of Wildlife Management 63:530-538.

Mecozzi, G. E., and F. S. Guthery. 2008. Behavior of walk-hunters and pointing dogs during northern bobwhite hunts. Journal of Wildlife Management 72:1399-1404.

Mehmood, S., D. Zhang, and J. Armstrong. 2003. Factors associated with declining license sales in Alabama. Human Dimensions of Wildlife 8:243-262.

Melo, R. A., D. Rodriguez, and D. Zarruk. 2018. Package 'gmapsdistance.' https://github.com/rodazuero/gmapsdistance. Accessed 08 Oct 2019.

Midwest Pheasant Study Group. 2013. National wild pheasant conservation plan. N.B. Veverka, editor. Association of Fish and Wildlife Agencies, Washington, D.C., USA.

Miller, C. A., and A. R. Gaefe. 2001. Effect of harvest success on hunter attitudes toward white-tailed deer management in Pennsylvania. Human Dimensions of Wildlife 6:189-203.

Miller, C., and J. Vaske. 2003. Individual and situational influences on declining hunter effort in Illinois. Human Dimensions of Wildlife 8:263-276.

Mozumder, P., C. M. Starbuck, R. P. Berrens, and S. Alexander. 2007. Lease and fee hunting on private lands in the U.S.: a review of the economic and legal issues. Human Dimensions of Wildlife 12:1-14.

National Oceanic and Atmospheric Association. 2016. Nebraska Climate Normals. https://nsco.unl.edu/climate-data. Accessed 16 Sep 2019.

Nebraska Game and Parks Commission. 2016a. Small game guide. Nebraska Game and Parks Commission, Lincoln, USA.

Nebraska Game and Parks Commission. 2016b. 2016 Public access atlas. Nebraska Game and Parks Commission, Lincoln, USA.

Nebraska Game and Parks Commission. 2016c. The Berggren plan: Nebraska's mega plan improving pheasant hunting. Nebraska Game and Parks Commission, Lincoln, USA. <http://outdoornebraska.gov/ pheasantplan/>. Accessed 08 Oct 2019.

Nebraska Game and Parks Commission. 2017. 2017 Upland Game Hunting Outlook. Nebraska Game and Parks Commission, Lincoln, USA. <https://outdoornebraska.gov/wp-content/uploads/2017/08/2017Nebraska-Forecast-FINAL.pdf>. Accessed 08 Oct 2019. 
Offenbach, L. A., and B. K. Goodwin. 1994. A travel-cost analysis of the demand for hunting trips in Kansas. Review of Agricultural Economics 16:55-61.

Oliver, R. L. 1980. A cognitive model of the antecedents and consequences of satisfaction decisions. Journal of Marketing Research 17:460-469.

Pabian, S. E., A. M. Wilson, S. R. Klinger, and M. C. Brittingham. 2015. Pennsylvania's Conservation Reserve Enhancement Program benefits ring-necked pheasants but not enough to reverse declines. Journal of Wildlife Management 79:641-646.

Parton, W. J., M. P. Gutmann, S. A. Williams, M. Easter, and D. Ojima. 2005. Ecological impact of historical land-use patterns in the Great Plains: a methodological assessment. Ecological Applications 15:1915-1928.

Plummer, M., N. Best, K. Cowles, K. Vines, D. Sarkar, D. Bates, R. Almond, and A. Magnusson. 2016. coda: output analysis and diagnostics for MCMC. https://cran.r-project.org/web/packages/coda/index. html. Accessed 08 Oct 2019.

Pollock, K. H., C. M. Jones, and T. L. Brown. 1994. Angler survey methods and their applications in fisheries management. American Fisheries Society Special Publication 25, Bethesda, Maryland, USA.

R Core Development Team. 2018. R: a language and environment for statistical computing. R Foundation for Statistical Computing, Vienna, Austria.

Ratcliffe, B. C., and P. C. Hammond. 2002. Insects and the native vegetation of Nebraska. Transactions of the Nebraska Academy of Sciences 28:29-47.

Responsive Management and the National Wild Turkey Federation. 2011. Effectiveness of hunting, shooting, and fishing recruitment and retention programs: final report. Responsive Management, Harrisonburg, Virginia, USA, and National Wild Turkey Federation, Edgefield, South Carolina, USA. <http://www.michigandnr.com/FTP/wildlife/aversb/ MWL/Hunting_Heritage/Responsive\%20Management_R\%20and\%20R\% 20Evaluation\%20Report\%202011.pdf>. Accessed 08 Oct 2019.

Ribot, J. C., and N. L. Peluso. 2009. A theory of access. Rural Sociology 68:153-181.

Ryan, E. L., and B. R. Shaw. 2011. Improving hunter recruitment and retention. Human Dimensions of Wildlife 16:311-317.

Schroeder, S. A., D. C. Fulton, and J. S. Lawrence. 2006. Managing for preferred hunting experiences: a typology of Minnesota waterfowl hunters. Wildlife Society Bulletin 34:380-387.

Schulz, J., J. Millspaugh, D. Zekor, and B. Washburn. 2003. Enhancing sport-hunting opportunities for urbanites. Wildlife Society Bulletin 31:565-573.

Sigmon, M. R. 2004. Hunting and posting on private land in America. Duke Law Journal 54:549-585.

Snellman, K., J. M. Silva, and R. D. Putnam. 2015. Inequity outside the classroom: growing class differences in participation in extracurricular activities. Voices in Urban Education 40:7-14.

Stayton, B. J. 2017. Colleges and universities: prime habitat for hunter recruitment and retention. Thesis, Clemson University, South Carolina, USA.

Stedman, R. C., P. Bhandari, A. E. Luloff, D. R. Diefenbach, and J. C. Finley. 2008. Deer hunting on Pennsylvania's public and private lands: a two-tiered system of hunters? Human Dimensions of Wildlife 13:222-233.

Stuber, E. F., L. F. Gruber, and J. J. Fontaine. 2017. A Bayesian method for assessing multi-scale species-habitat relationships. Landscape Ecology 32:2365-2381.

Taylor, J. S., T. R. Bogenschutz, and W. R. Clark. 2018. Pheasant responses to U.S. cropland conversion programs: a review and recommendations. Wildlife Society Bulletin 42:184-194.

Tomeček, J. M., B. L. Pierce, and M. J. Peterson. 2015. Quail abundance, hunter effort, and harvest of two Texas quail species: implications for hunting management. Wildlife Biology 21:303-311.

U.S. Census Bureau. 2018a. American Community Survey. https://www. census.gov/programs-surveys/acs/. Accessed 16 Apr 2018.

U.S. Census Bureau. 2018b. State area measurements and internal point coordinates. https://www.census.gov/geo/reference/state-area.html. Accessed 16 Apr 2018.
U.S. Department of Agriculture National Agricultural Statistics Service. 2012. The yield forecasting program of NASS. Statistical Methods Branch Report SMB 12-01. National Agricultural Statistics Service, Washington, D.C., USA.

U.S. Fish and Wildlife Service. 2018. 2016 National surveys of fishing, hunting, and wildlife-associated recreation. U.S. Department of the Interior, U.S. Fish and Wildlife Service, and U.S. Department of Commerce, U.S. Census Bureau, Washington, D.C., USA.

U.S. Geological Survey. 2018. The public land survey system (PLSS). https://nationalmap.gov/small_scale/a_plss.html. Accessed 16 Apr 2018.

Vaske, J. J., A. J. Fedler, and A. R. Graefe. 1986. Multiple determinants of satisfaction from a specific waterfowl hunting trip. Leisure Sciences 8:149-166

Vrtiska, M. P., J. H. Gammonley, L. W. Naylor, and A. H. Raedeke. 2013. Economic and conservation ramifications from the decline of waterfowl hunters. Wildlife Society Bulletin 37:380-388.

Walberg, E., L. Cornicelli, and D. C. Fulton. 2018. Factors impacting hunter access to private lands in southeast Minnesota. Human Dimensions of Wildlife 23:101-114.

Ward, K. J., R. C. Stedman, A. E. Luloff, J. S. Shortle, and J. C. Finley. 2008. Categorizing deer hunters by typologies useful to game managers: a latent-class model. Society \& Natural Resources 21:215-229.

Warner, R., S. Etter, G. Joselyn, and J. Ellis. 1984. Declining survival of ring-necked pheasant chicks in Illinois agricultural ecosystems. Journal of Wildlife Management 48:82-88.

White, K. J. C. 2008. Population change and farm dependence: temporal and spatial variation in the U.S. Great Plains, 1900-2000. Demography 45:363-386.

White, K. J. C., and A. M. Guest. 2003. Community lost or transformed? Urbanization and social ties. City and Community 2:239-259.

Wright, C. K., and M. C. Wimberly. 2013. Grassland conversion in the Western Corn Belt. Proceedings of the National Academy of Sciences 110:4134-4139.

Associate Editor: Lincoln Larson.

\section{SUPPORTING INFORMATION}

Additional supporting information may be found in the online version of this article at the publisher's website.

\section{APPENDIX A: INTERVIEW QUESTIONS}

- How many adult males are in your party today? $(0-5)$

- How many adult females are in your party today? $(0-5)$

- How many youth are in your party today? $(0-5)$

- What are your home ZIP codes?

- What year were you (everyone) born?

-What was the primary species you were hunting for today?

- Did you hunt with dogs today?

o If yes, how many dogs? (0-4)

- Do you have access to hunt for pheasants on private lands in the area?

- How many total pheasants did you see while hunting on this property?

- On a scale of 1 to 5 with 1 being low and 5 being high, how would you rate the extent to which this hunt met your expectations?

o 1 = failed to meet expectations, $3=$ met expectations, $5=$ exceeded expectations.

- Did you harvest any pheasants at this property?

- How many pheasants did you harvest at this property? 